\title{
Filozoficzny potencjał podmiotowości w świetle koncepcji lęku Jacques'a Lacana
}

Marta Szabat 


\section{Roztrząsania i rozbiory}

\section{Filozoficzny potencjał podmiotowości w świetle koncepcji lęku Jacques'a Lacana}

Marta Szabat

TEKSTY DRUGIE 2017, NR 4, S. 96-114

DOI: $10.18318 /$ td.2017.4.6

\section{Wstęp}

Z jednej strony zagadnienie lęku w filozofii wydaje się problematyczne ze względu na swój psychologiczny charakter. Lęku nie sposób zdefiniować ani świadomie kontrolować. Stąd tego rodzaju tematyka może zostać uznana za nienadającą się do systematycznej analizy. $\mathrm{Z}$ drugiej strony wymienione czynniki oraz nieokreśloność a jednocześnie prawdziwość odczuwania lęku w różnego typu sytuacjach zachęcają reprezentantów zawodów medycznych, terapeutów, w tym myślicieli, do zajęcia się tytułowym zagadnieniem. Tematyka ta została obszernie opracowana w filozofii egzystencjalnej oraz w psychologii i psychiatrii. Przedstawicielem tej ostatniej jest francuski analityk Jacques Lacan, który, bazując na własnej praktyce klinicznej, dokonał czegoś więcej niż tylko opisu i klasyfikacji lęku. Autor seminarium L'angois$s e$ [Lęk], na którym opieram swoje analizy, wskazał na lęk jako zasadniczą przypadłość podmiotowości, bez której nie mogłaby ona zachować swojego specyficznego statusu. W niniejszym artykule z jednej strony przedstawię

Marta Szabat $-d r$, adiunkt, pracownik Zakładu Filozofii i Bioetyki UJCM. Autorka książki Elementy filozofii opieki paliatywnej a zagadnienie śmierci (2013), stypendystka rządu francuskiego (2012) oraz Fundacji na rzecz Nauki Polskiej (2015). Redaktor naczelna filozoficznego czasopisma internetowego "Edukacja Etyczna" [www. edukacjaetyczna. pl]. Kontakt: marta. szabat@uj.edu.pl 
te aspekty lęku charakterystyczne dla podmiotowości, które mogą przyczynić się do lepszego wykorzystania potencjału tej ostatniej. Z drugiej zaś strony pogłębię rozważania Lacana, odnosząc się do myślicieli takich jak: Immanuel Kant, Paul Ricœur, Emmanuel Lévinas.

\section{Lacanowska koncepcja lęku a podmiotowość}

Tytułowe zagadnienie omawiane w Lacanowskim seminarium, mianowicie lęk, ściśle wiąże się z tym, co francuski psychoanalityk nazywa pragnieniem Innego (le désir de L'Autre). To ostatnie zaś nie jest jakimś nieokreślonym rodzajem pragnienia, lecz oznacza pragnienie akceptacji ze strony Innego. Lacan wypowiada to pragnienie za pomocą serii pytań: czego chce on (Inny) dla mnie (Que veut-Il à moi)? Jak on mnie chce (Comment me veut-Il)? [wydaje się, że to pytanie można sparafrazować również w formie: Kim on chce abym byt dla niego?; wydaje się to możliwe, tym bardziej że następne pytanie francuskiego psychoanalityka brzmi: Czego on chce, odnosząc się do miejsca Ja? (Que veut-Il concernant cette place du moi?]'. Co więcej, tego rodzaju pragnienie nie jest intencjonalne - jeżeli Ja pragnie Innego, to dzieje się tak w celu ustanowienia siebie samego, które raczej nie rozgrywa się na poziomie świadomym, tym bardziej że Ja konstytuuje się od chwili narodzin. Osiągając zaś dojrzałość, podmiot niekoniecznie musi interesować się sobą samym w ten sposób, że wyjaśnia motywy własnych pragnień czy odtwarza sposób, w jaki uzyskiwał swoją „tożsamość” w dzieciństwie.

W tym miejscu warto dokonać istotnego rozróżnienia Ja (Ego) od podmiotu, który konstytuuje się na poziomie symbolicznym, w odróżnieniu od Ja (porządek wyobrażeniowy). W porządku wyobrażeniowym Ja dokonuje identyfikacji, która, według Lacana, nigdy nie może być faktyczna i pełna. W porządku symbolicznym zaś podmiot (S) pozostaje w relacji do Innego (A) utożsamiającego go z obiektem jego pragnienia, którym jest nie on sam jako A, lecz on jako przekreślone A, czyli brak - Inny uznaje obiekt (\$), konstytuując go jako obiekt. Podmiot konstytuuje się w miejscu Innego, w tym miejscu braku. Z drugiej strony Inny potrzebuje podmiotu w braku, w tym, czego nie ma - Inny to miejsce znaczące (C'est L'Autre comme lieu de signifiant) ${ }^{2}$.

1 J. Lacan Le Séminaire, livre X, L'angoisse, Seuil, Paris 2004, S. 14. W tym miejscu chciałabym podziękować Pani Annie Turczyn za tłumaczenie seminaryjne tekstu X seminarium. Dzięki możliwości skorzystania z tego tłumaczenia mogłam lepiej zrozumieć koncepcję lęku J. Lacana.

2 Zob. tamże, s. 33. 
Mikkel Borch-Jacobsen w swoich wykładach na temat Lacanowskiej teorii rozumie różnicę między Ja i podmiotem jako tym, który „się przegląda” w Innym (Ja; se voit dans l'autre) oraz tym, który mówi (podmiot; parle à l'autre). Podmiot to ten, który mówi. Wzajemne funkcjonowanie zaś Ja i podmiotu można ujmować w kategoriach dialektycznego „konfliktu”. Potwierdzenie takiego ujęcia znajdujemy u samego Lacana m.in. w seminarium III Psychozy: „podmiot mówi się swoim ja [se parle avec son soi] "4; podmiot psychotyczny „dosłownie rozmawia ze swoim ja, i to tak, jak gdyby ktoś trzeci, jego dubler, mówił i komentował jego poczynania"5. Ja konstytuuje się więc w Innym i to w nim się ono zaczyna, jako Ja. W dyskusji z Lacanem Henri Maldiney określił owo rozróżnienie konstytuujące wymiar przed-słowny i słowny „dwoma podmiotami”. Ja identyfikuje się z samym sobą na poziomie pozawerbalnym, wyobrażeniowym. Podmiot zaś, aby się ukonstytuować na poziomie symbolicznym, nie tylko potrzebuje Ja, lecz także kontekstu językowego ${ }^{6}$.

W teorii Lacana, podobnie jak u Freuda, lęk nie jest emocją. Ma on pewną strukturę. Francuski psychoanalityk stwierdza, że próbując ustalić, „miejsce” lęku można stwierdzić, że jest on afektem? (afekt nie zostaje wyparty, lecz jest przełożony, przemieszczony; afekt może oznaczać sygnał niebezpieczeństwa, ostrzeżenie). W pracy Zahamowanie, symptom, lęk Zygmunt Freud sygnalizuje, że lęk to sygnał wskazujący na utratę obiektu. Do ujęcia lęku dochodzi on przez analizę zahamowania i symptomu stanowiących nieodłączne składniki lęku. Lęk może ujawniać się za pośrednictwem symptomu i wywoływać zahamowanie ${ }^{8}$. Lacan podkreśla jeszcze coś - lęk pojawia się wówczas, gdy podmiot zaczyna "przeczuwać" istnienie reszty - $a$, czyli wtedy gdy świat zaczyna być „podwójny".

Lacan porównuje kształtowanie się podmiotu do wchodzenia na scenę. Najpierw niezredukowany świat, a następnie wznoszenie inscenizacji. $\mathrm{Na}$

3 Zob. M. Borch-Jacobsen Lacan. Le maître absolu, Flammarion, Paris 1990, s. 96, 104-108.

4 J. Lacan Seminarium III. Psychozy, przeł. J. Waga, PWN, Warszawa 2014, s. 28.

5 Tamże, s. 29.

6 Zob. J. Lacan Mon enseignement, Éditions du Seuil, Paris 2005, s. 66-73.

7 Zob. J. Lacan Le Séminaire, livre X, L'angoisse, s. 23,28.

8 Z. Freud Zahamowanie, symptom, lęk, przeł. R. Reszke, w: tegoż Histeria i lęk, przeł. R. Reszke, KR, Warszawa 2001, S. 199-220.

9 J. Lacan Le Séminaire, livre X, L'angoisse, s. 66. 
scenę podmiot wchodzi już w masce ${ }^{10}$. Między wchodzeniem na scenę a relacją wyobrażeniową można przeprowadzić pewną analogię - podobnie jak na scenie, tak i w relacji wyobrażeniowej kluczową rolę odgrywa obsadzenie (linvestissement) ${ }^{11}$. Ma ono swoją granicę, poza którą pozostaje reszta, o której wspomnieliśmy wyżej. Co więcej, przed uniesieniem kurtyny może pojawić się niepokój, a u niektórych nawet lęk. Lęk ma swoje granice, stąd może mieć formę fantazmatu ${ }^{12}$. W kontekście braku warto wspomnieć pewien typ symptomu nazwany przez Lacana acting out. W tym przeniesieniu podmiot daje to, czego nie ma, tzn. stawia samego siebie w miejscu braku, wykonuje acting out ${ }^{13}$, wchodzi na scenę, aby coś oznaczycit . W momencie jednak gdy cięcie zaczyna być widoczne i pojawiają się sygnały realnego oraz pojawia się lęk jako funkcja braku (brak można rozpoznać jedynie na poziomie symbolicznym; w realnym nie sposób ująć braku), podmiot zrzuca siebie ze sceny, wykonuje passage à l'acte:

Kiedy - pomimo nacisków znaczącego - znaczenie nie jest słyszane, dochodzi do negatywnego przeniesienia. Gdy analizant wskutek tego rodzaju „głuchoty" rezygnuje z analizy, jest to właśnie passage à l'acte. ${ }^{15}$

Relacja wyobrażeniowa ściśle wiąże się z porządkiem libido. Fallus występuje w niej jako puste miejsce, jako miejsce braku, jest on jednak „wycięty” (coupé) $\mathrm{z}$ obrazu lustrzanego (można to rozumieć jako formę kastracji) ${ }^{16}$. Fallus nie jest resztą, lecz jest po stronie porządku wyobrażeniowego jako swoista rezerwa, nie obsadza się na poziomie obrazu lustrzanego, ponieważ pozostaje głęboko obsadzony na poziomie narcystycznym, na poziomie ciała własnego, na poziomie pierwotnym. Hermann Lang komentuje ten wątek Lacanowskiej teorii dość jednoznacznie:

10 Tamże, s. 44.

11 Zob. tamże, s. 50.

12 Zob. tamże, s. 89.

13 Więcej na ten temat, wraz z przykładem Dory zob. tamże, s. 137-153. Zob. też: J. Lacan Wprowadzenie do Imion-Ojca, w: tegoż Imiona-Ojca, przeł. R. Carrabino, T. Gajda, J. Kotara, B. Kowalów, A. Kurek, PWN, Warszawa 2013, s. 63-82.

14 Zob. M. Safouan Cztery lekcje psychoanalizy. Metoda Lacana, przeł. J. Groth, Gdańskie Wydawnictwo Psychologiczne, Sopot 2012, s. 31-32.

15 Zob. tamże. 
Na poziomie czysto „realnym” teza o prymacie fallusa byłaby nie do pomyślenia. Przedmiot, jakim jest penis, staje się symbolem samego siebie jako nieobecnego, w akcie symbolicznej retroakcji - [...] staje się znaczącym - dla wszystkich tych utraconych przedmiotów, które poprzedzają kastrację [...].W ten sposób dostrzegamy w znaczącym, jakim jest fallus, znak braku, który przybierając coraz to nową postać jednego z tych niepodlegających spekulacji „obiektów $\alpha$ ”, rodzi pragnienie, którego jedynym celem jest odnalezienie utraconego. Jeżeli wcześniej mówiliśmy o tym, że to właśnie władająca językiem strata toruje drogę pragnieniu i określaliśmy tę przestrzeń nieobecności za pomocą sygnantu -1 (lub $S(\AA)$ ), to teraz okazuje się, że ucieleśnieniem tej „logicznej” luki jest właśnie fallus. Kompleks kastracji możemy więc traktować jako zjednoczenie realnej cielesności i porządku symbolicznego. ${ }^{17}$

Warto podkreślić, że symbolika fallusa ściśle łączy się ze jouissance, tzn. z dwuznacznym charakterem samej przyjemności, szczęścia czy radości. Z jednej strony Freud nazywał ten rodzaj popędu popędem Erosa, fallus oznacza życie, rozmnażanie, rozkosz. Z drugiej jednak, we Freudowskiej teorii mamy popędy destrukcyjne, którym patronuje grecki bóg śmierci - Tanathos, fallus to prawo, obowiązki, brzemię i śmierć. Safouan ujmuje status podmiotu następująco:

W istocie podmiot od samego początku jest degradowany poprzez symboliczną kastrację. Degradacja ta zmusza go do przyjęcia szczególnego rodzaju braku manifestującego się na poziomie wyobrażeniowym jako niedostatek, który piętnuje lustrzany obraz podmiotu. Jednocześnie pragnienie ma tylko dwa oblicza: jednym jest prawo, drugim zaś wykroczenie. Można by rzec, że podmiot jest umiejscowiony w samym braku, jest tym brakiem, fallusem, który Lacan przedstawia symbolicznie jako $-\varphi .^{18}$

Wszędzie tam, gdzie mowa o lęku, chodzi o związek z $a$, które, jak już wyżej zostało zaznaczone, w podmiocie pojawia się tylko w porządku wyobrażeniowym jako obraz lustrzany i(a), w którym i(a) jest, za każdym razem,

17 H. Lang lęzyk i nieświadomość. Podstawy teorii psychoanalitycznej Jacques'a Lacana, przeł. P. Piszczatowski, słowo/obraz terytoria, Gdańsk 2005, s. 334-335. rozwoju Lacanowskiej teorii w zakresie koncepcji fallusa zob. m.in. C. Clément Vies et légendes de Jacques Lacan, Édition Grasset \& Fasquelle, Paris 1981, s. 212-217. 
poświadczane przez Innego. Lęk pojawia się wówczas, gdy w miejscu braku (fallusa, $-\varphi$ ) pojawia się coś, cokolwiek (quelque chose, n'importe quoi) ${ }^{19}$. Francuski psychoanalityk odwołuje się do Freudowskiego terminu Unheimlichkeit na oznaczenie tego czegoś - braku zaczyna brakować (le manque vient à manquer) ${ }^{20}$. Ja staje się „nie-swoje” w relacji wyobrażeniowej, zaczyna czuć się nieswojo. Unheimlichkeit można rozumieć również jako to, co niesamowite $^{21}$. Heim oznacza także dom i to jest miejsce, w którym lęk się ujawnia. Podmiot zaczyna rozumieć, że jest jeszcze coś poza „domem”, tzn. poza jego własną podmiotową strukturą, która została określona jako wyobrażeniowa, w Innym. Podmiot zaczyna rozumieć, że nie jest niezależny, w pewien sposób można powiedzieć, że „traci” swoją autonomię, której nigdy nie „miał”22. Może się nawet zdarzyć tak, że podmiot zacznie zdawać sobie sprawę z tego, że jest obiektem w miejscu braku Innego, jednak równocześnie musi uświadomić sobie brak dostępu do $a$. Jeżeli chciałby uzyskać dostęp do swojego pragnienia, to jedyną rzeczą, która mu pozostaje, jest wejście w rolę obiektu dla jakiegoś Innego. Lacan podkreśla, że w miejscu lęku budzi go nie brak, lecz brak możliwości braku, obecność innego obiektu w miejscu braku. Obiekt domaga się obecności w miejscu braku, chociaż nie powinno go tam być, stąd lęk podmiotu przed tego rodzaju anomalią 23 .

Lacan zwraca uwagę na to, że zwierzęta, wytwarzając ślady i oznaczając w ten sposób własne terytorium, nie fałszują śladów. Fałszowanie jest przypadłością stricte ludzką - podmiotową. Swoje spostrzeżenia opiera na eksperymentach doświadczalnych na zwierzętach ${ }^{24}$. Odnosząc się do podmiotu, Lacan stwierdza: Znaczacy bez wattienia ujawnia podmiot, lecz wymazujac ślad²5.

Jak już zwróciłam uwagę wyżej, podmiot rozpoznaje siebie jako obraz, nie rozpoznaje własnych śladów. Warto zwrócić uwagę, że właśnie ten aspekt nieświadomego francuski psychoanalityk określa mianem Unbewusste ${ }^{26}$. Co

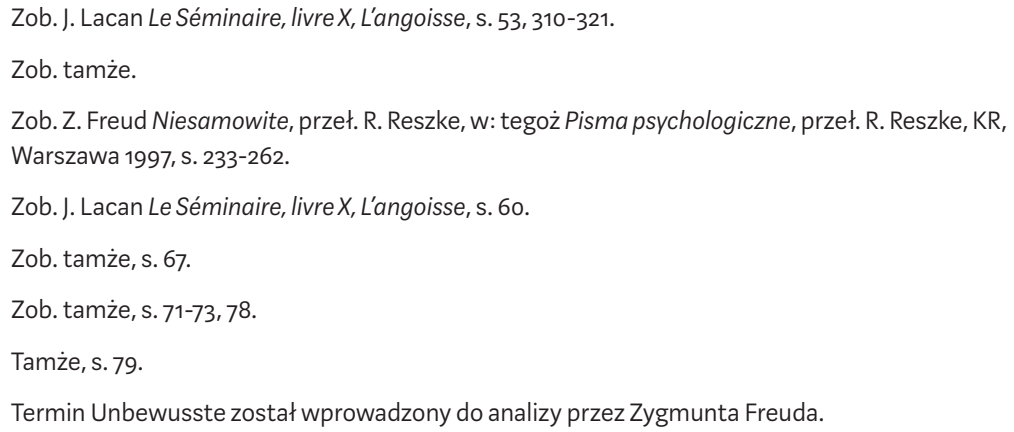


więcej, podmiot jest cielesny, co utrudnia mu uchwycenie samego siebie również jako $i(a)^{27}$.

Zdaniem Lacana przekonanie o tym, że lęk nie ma obiektu, jest fałszywe - lęk występuje z obiektem i nie pojawia się bez niego ${ }^{28}$. Lęk to cięcie (cette coupure), konieczne do tego, aby podmiot mógł się ukonstytuować jako $\$^{29}$. Interesującą metaforą tego cięcia jest rytuał obrzezania, zgodnie z którym „Bóg”/ Prawo domaga się wydobycia podmiotu - fallusa - za pośrednictwem koniecznego rytualnego „cięcia”. Obrzezanie dotyczy zarówno dziewczynek/kobiet, jak i chłopców/mężczyzn, a jedną z jego zasadniczych funkcji jest uwidocznienie i podkreślenie rozdzielności kobiecości i męskości ${ }^{30}$. Dokonuje się ono, podobnie jak kastracja, również na poziomie symbolicznym i wyobrażeniowym.

Oprócz tego, że lęk wychodzi na jaw jako sygnał, to również ujawnia się w braku samego siebie, w tym, że małego $a$ nie ma już w podmiocie, któremu siebie samego brak ${ }^{31}$. Czym byłby zatem sygnał lęku? Ujawnia się on na poziomie podmiotowym, lecz ten, jak już zwracaliśmy uwagę, jest poświadczany przez Innego. Należy więc przyjąć, że lęk przeznaczony jest dla Innego, mimo że jest uznawany przez podmiot za jego własny. W ten sposób podmiot zostaje uprzedzony o domaganiu się ze strony Innego ${ }^{32}$. Na poziomie symbolicznego podmiot przeczuwa „cięcie”, podwójność, fakt, że nie jest sam dla siebie, że to Inny, za jego pośrednictwem, domaga się czegoś dla siebie. Lęk podmiotu byłby zatem tym, co sygnalizuje mu „prawdę”. Domaganie się wychodzi na jaw, jeszcze zanim dojdzie do ukonstytuowania podmiotu jako obiektu dla Innego. Lęk dochodzi do głosu na poziomie podmiotowej nieświadomości, po stronie Innego.

W rozdziale XII L'angoisse autor odnosi się do typowego w literaturze przedmiotu rozróżnienia na lęk (l'angoisse) i strach (la peur). Powołuje się tutaj na Freuda, który stwierdza, że, jeżeli chodzi o oczekiwanie, to lęk jest zawsze

Zob. J. Lacan Le Séminaire, livreX, L'angoisse, s. 104. Na temat podmiotu w teorii Lacana zob.m.in. A. Vergote Le sujet inconscient selon Lacan, w: La pensée de Jacques Lacan. Questions historiques - Problèmes théoriques, réd. S.G. Lofts, P. Moyaert, Éditions Peeters, Louvain-Paris 1994, S. 1-22; D. Nobus Le sujet selon Lacan: entre linguistique et topologie, w: Lacan, réd. ..-M. Rabaté, Bayard, Paris 2005, s. 73-91.

Zob. J. Lacan Le Séminaire, livre X, L'angoisse, s. 105.

Zob. tamże, s. 92.

Zob. tamże, s. 97.

Zob. tamże, s. 139-142. 
lękiem przed czymśs ${ }^{33}$. Jednak Freud wydaje się przychylać do stanowiska, zgodnie z którym strach odnosi się do obiektu, a lęk przeciwnie. W pracy $Z a$ hamowanie, symptom, lęk Freud stwierdza:
Afekt lęku wykazuje kilka cech, których zbadanie wiąże się z obietnicą głębszego wyjaśnienia tego zjawiska. Lęk w sposób niewątpliwy odnosi się do oczekiwania; jeżeli lęk się pojawia, to jest to lęk przed czymś. Z lękiem związane są cechy nieokreśloności i braku obiektu; w sytuacji, gdy afekt ten znalazł swój obiekt, nawet poprawność językowa każe zmieniać to miano, zastępując je pojęciem „strachu".34

Lacan inaczej rozumie status lęku. Dowodzi, że jest on zawsze związany z obiektem, nigdy nie dotyczy braku obiektu. Lęk to sygnał, który sytuuje się w porządku nieredukowalnego realnego ${ }^{35}$. W kontekście rozważań nad obiektem, do którego odnosi się lęk, francuski psychoanalityk podaje przykład Edypa, który zobaczył, co zrobił. Uciekając od przepowiedni, lękając się jej, wpadł prosto w sidła przeznaczenia. Jednak to tragiczna historia Edypa ukonstytuowała go jako podmiot. Na podstawie Lacanowskich analiz można stwierdzić, że lęk jako sygnał jest zalążkiem podmiotowości, konstytuuje się jako zakrywający realne (a). Dotykając człowieka, lęk sygnalizuje mu jego własną intymnośćs ${ }^{36}$. Lęk „pośredniczy” między jouissance i pragnieniem podmiotu. Jest obecny w konstytuowaniu się pragnienia:

Pragnienie w istocie konstytuuje się po tej stronie strefy, która oddziela jouissance i pragnienie, i która jest słabym punktem, w którym powstaje lęk. To nie znaczy, że pragnienie nie dotyczy Innego zainteresowanego w jouissance, który jest Innym realnym. Powiedziałbym, że normatywne jest to, iż pragnienie, prawo, które stanowi pragnienie jako pragnienie, nie dochodzi do odniesienia się do tego Innego w jego centrum. Prawo odnosi się do niego tylko ekscentrycznie i z boku - małe a, substytut dużego A. ${ }^{37}$

\footnotetext{
33 S. Freud Zahamowanie, symptom, lęk, w: tegoż Histeria i lęk, Dzieła tom VII, przeł. R. Reszke, KR, Warszawa 2001, s. 265. Tamże. Zob. tamże, s. 202.

Tamże, s. 213. Tłumaczenie seminaryjne Anny Turczyn.
} 
Doprecyzowując status pragnienia, Lacan podkreśla, że pozostaje ono pragnieniem ciała Innego ze strony podmiotu ${ }^{38}$. Cielesny charakter pragnienia doprecyzowuje jednocześnie status samego podmiotu pozostającego przede wszystkim podmiotem cielesnym - pragnienie Innego jako jego ciała animuje percepcję oraz intencjonalnośćn ${ }^{39}$.

Lacan proponuje strukturę l'émoi w odniesieniu do moi (Ja), które kształtuje się niejako poza samym sobą na „obraz i podobieństwo” Innego. L'émoi zbliżałoby się ku małemu a, ku realności Ja ${ }^{40}$. Lęk (l'angoisse) nie tylko nie może istnieć bez przedmiotu, lecz także współtworzy przedmiot, wobec którego Ja odczuwa lęk. Ja w swoim nieustannym odniesieniu do Innego trwoży się na myśl lub na widok tego, co francuski psychoanalityk nazywa la Chose (Rzecz), czyli tego, co faktycznie mogłoby być Ja - pustki, traumy itp. Inaczej mówiąc, Ja lęka się odkryć w sobie l'émoi jako to, co realne. W seminarium Touché et automaton ${ }^{41}$ Lacan zwraca uwagę na fakt, że realność nie jest asymilowalna ani przez Ja, ani przez podmiot. Nie jest to możliwe, stąd Ja wytwarza rzeczywistość jako swoiste antidotum na realne. Wytwarzanie rzeczywistości odbywa się od momentu najbardziej wczesnej relacji z obiektem - piersią matki dającą mleko czy ze smoczkiem z butelki na mleko ${ }^{42}$. Zależność od obiektu, którego Ja potrzebuje od samego początku, czyni z niego samego strukturę pękniętą, zawsze odnoszącą się do tego, co inne. Realne zaś pozostaje zawsze poza możliwościami jakiejkolwiek analizy ${ }^{43}$.

$\mathrm{Na}$ zakończenie tego podrozdziału warto podjąć ostatni wątek: podmiotu, który przestaje ulegać swojemu pragnieniu i przestaje odczuwać lęk. Wątek ten podejmuje Lacan w Seminarium VII zatytułowanym L'éthique de

38 "Le désir reste toujours au dernier terme désir du corps, désir du corps de L'Autre, et rien que désir de son corps". Tamże, s. 249.

Zob. tamże, s. 251-253.

40 "[...] l'émoi dont il'agit n'est rien d'autre que le $a$ lui-même, au moins dans les corrélations que nous tentons d'explorer, de dénouer, de créer aujourd'hui, à savoir les rapports du désir et de l'angoisse". Tamże, s. 360.

41 Zob. J. Lacan Touché i automaton, przeł. K. Kłosiński, w: Teorie literatury XX wieku. Antologia, red. A. Burzyńska, M.P. Markowski, Znak, Kraków 2007, s. 30-41. Zob. J. Lacan Le Séminaire, livre X, L'angoisse, s. 362-363.

43 S. Schneiderman zwraca uwagę na fakt, że w analizie „nie dzieje się nic realnego; realne zawsze musi pozostawać na zewnątrz", Jacques Lacan. Śmierć intelektualnego bohatera, Wydawnictwo Andrzej Żórawski, Warszawa 2004, s. 49. 
la psychanalys $e^{44}$. W seminarium podjęty zostaje problem granic, do jakich podmiot może się posunąć w swoim pragnieniu i w ich realizacji, ażeby nie przeobrazić się w automat, zimny twór, niewrażliwy na otoczenie. W momencie bowiem, kiedy podmiot dochodzi do kresu własnych możliwości, co może oznaczać, jak ujmuje to Paul Moyaert, że pragnienie uderza w wartość-graniczna, której nie jest w stanie przekroczyc ${ }^{45}$, wówczas podmiot przestaje ulegać swojemu pragnieniu. Oznacza to, że przestaje odczuwać strach przed utratą przywiązania ze strony Innego, ponieważ, w swoim mniemaniu, nie zależy już od niego:

Nie skłania się ku radom i sądom innych i nie jest już zdeterminowany rachunkiem konsekwencji swoich słów lub czynów. Wreszcie przestaje go ograniczać troska o własne szczęście: uwalnia się od pytania o to, czy będzie czy nie będzie wychwalany przez poetów albo czy jego ofiara spodoba się bogom... Jego pragnienie staje się czystym pragnieniem, czyli oczyszczonym z wszelkich granic. W swojej skrajnej wrażliwości na wartość, staje się podmiotem niewrażliwym i bezlitosnym i upodabnia się do podmiotu „bez lęku i bez litości”. Ponieważ podmiot, którego nic nie ogranicza, jest w istocie podmiotem zdolnym do wszystkiego. Najbardziej niepokojącym podmiotem jest podmiot, który niczego się nie boi, jak podmiot budzący największą odrazę i nieczujący wstrętu do niczego. ${ }^{46}$

Najważniejszym przesłaniem analizowanej teorii jest wniosek, że lęk zawsze odnosi się do obiektu i pojawia się wówczas, gdy podmiot przeczuwa istnienie fundamentalnej nie-tożsamości, jaką faktycznie byłby. Oznacza to, że jedność i iluzja tożsamości, jaką postuluje Lacan, pełnią w samej strukturze podmiotu zasadniczą funkcję. To owa wyobrażona i symboliczna „rzeczywistość” utrzymuje podmiot w przekonaniu o własnej tożsamości. Lęk sygnalizuje obiekt zagrażający iluzji, stąd pochodzi on z porządku realnego związanego nie z iluzją lecz z prawdą. Podmiot zatem nie tylko lęka się prawdy, lecz także

44 J. Lacan Le Séminaire VII. L'éthique de la psychanalyse, Éditions du Seuil, Paris 1986.

P. Moyaert Sur la sublimation chez Lacan: quelques remarques, w: La pensée de Jacques Lacan. Questions historiques - Problèmes théoriques, réd. S.G. Lofts, P. Moyaert, Éditions Peeters, Louvain-Paris 1994. Podaję cytat za tłumaczeniem: P. Moyaert O sublimacji u Lacana: kilka uwag, przeł. A. Turczyn, „Edukacja Etyczna” 2013 nr 6, s. 29. 
musi trwać w iluzji własnej tożsamości, aby nie osunąć się w chaos, bezład, destrukcję. Moyaert próbuje ująć tego rodzaju podmiot, który nie byłby sobą, lecz monstrum, mechanicznym zlepkiem różnorodnych działań, możliwości i braku uczuć. Dopóki podmiot odczuwa lęk, pozostaje sobą samym, a iluzja tożsamości pełni swoją zasadniczą funkcję, jaką jest konieczność przeglądania się w I/innym jak w lustrze. Dopóki I/Inny ma dla podmiotu znaczenie, możliwe są więzi społeczne i wspólnotowe oparte na prawie. To ostatnie nie odgrywa oczywiście pozytywnej roli ani w teorii Freuda, ani tym bardziej u Lacana. Jednakże oderwanie podmiotu od prawa, czyli od I/innego, unicestwiłoby jakiekolwiek podmiotowe struktury - zarówno świadome, jak i nieświadome.

\section{Konsekwencje Lacanowskiej koncepcji lęku dla filozofii podmiotu}

Na podstawie tego, co zostało wyżej zaznaczone, można w konsekwencji stwierdzić, że Lacanowska koncepcja lęku to nie tylko diagnoza faktycznego stanu podmiotu jako de facto „pustego", wspierającego się na iluzjach, metonimiach i metaforach, lecz także swego rodzaju wskazówka odnośnie do wykorzystania możliwości tkwiących w lęku dla umocnienia podmiotowych pozycji. To dzięki odczuwaniu lęku podmiot staje wobec prawdy o samym sobie w pragnieniu. To w lęku podmiotowość pragnie. Obie struktury wydają się ściśle ze sobą powiązane, natura samego pragnienia nie wydaje się ani intencjonalna, ani wolicjonalna, ani tym bardziej instynktowna. Zdanie Lacana: pragnę cię, nawet jeżeli nie zdaję sobie z tego sprawy (Je te désire, même si je ne le sais pas) ${ }^{47}$ dobrze ilustruje sposób, w jaki Ja „funkcjonuje”. Otrzymując uznanie ze strony Innego, tzn. spełniając swoje pragnienie, Ja staje się obiektem uznania, zostaje uznane jako obiekt. Za pośrednictwem Innego staje się ono samo dla siebie uznanym obiektem (chciałoby się dodać: i niczym więcej!). Lacan wskazuje na to miejsce jako impas, trudność nie do pokonania ${ }^{48}$. W ten sposób tworzy się obraz Ja jako obiektu pragnienia, który nie jest, być może nigdy nie był i nie będzie, sam dla siebie, lecz jest obrazem samego siebie, który Lacan zapisuje symbolem i(a). Obraz, o jaki chodzi, nie jest, w tym wypadku obrazem lustrzanym, lecz jest to obraz, który może zostać nazwany fantazmatem. Francuski psychoanalityk stwierdza:

Zob. J. Lacan Le Séminaire, livre X, L'angoisse, s. 25. 
to pragnienie jest pragnieniem w ten sposób, że jego obraz-oparcie jest odpowiednikiem pragnienia Innego. ${ }^{49}$

W tej perspektywie Inny jest zaznaczany jako A ukośnie przekreślone, ponieważ w miejsce tego, czego brakuje Innemu, zostaje uznany obiekt $i$ (a). Pragnienie to brak Innego. Można wysnuć z tego wniosek, że Ja, o ile pragnie uznania Innego, o tyle jest swoim własnym obrazem (pragnieniem Innego), pozostawiając „resztę” czegoś - być może samego siebie, być może resztę tego, czego nigdy żadne inne Ja nie będzie mogło ani poznać, ani zobaczyć, ani przeczuć.

Najciekawsze wydaje się stwierdzenie Lacana, że to jednak nie i(a) pragnie, lecz pragnie $a$. Wobec tego można pokusić się o pytanie, skąd wiadomo, że to $a$ pragnie, skoro odbywa się to na poziomie nie tylko nieświadomym, lecz również na poziomie „reszty” nieuznanej przez Innego? Małe $a$ nie ma obrazu lustrzanego - jego status Lacan wyjaśnia na przykładzie wstęgi Möbiusa - po przecięciu wstęgi powstaje coś, co nie ma obrazu lustrzanego, reszta $-a^{50}$. Co więcej, $a$ to coś, czego już nie ma w Ja (qu'on n'a plus ${ }^{51}$ ).

Z jednej strony zatem podmiot lęka się prawdy o samym sobie. Z drugiej zaś odczuwa pragnienie odkrycia jej, zdając sobie sprawę, że nie jest to możliwe ze względu na status nie-pełni, pęknięcia. To z tego jednak pragnie, z fundamentalnej nietożsamości konstytuującej się w polu odziaływania Innego.

W filozofiach podmiotu współczesnych Lacanowi, takich jak np. myśl Emmanuela Lévinasa czy Paula Ricœura, również widoczna jest swoista dialektyka pragnienia i tego, co je ogranicza, na co Freud i Lacan wskazują jako na symptomy lęku. To na tym poziomie można obserwować sublimację dialektyki lęku i pragnienia, dzięki której możliwe jest postawienie pytania o potencjał lęku, z którego podmiotowość wychodzi w kierunku Innego. Podobnie jak u Lévinasa, podmiotowość Lacana staje się samą sobą wyłącznie w odniesieniu do Innego, czerpiąc z pragnienia, które ją motywuje. Pytaniem otwartym pozostaje jednak status pragnienia w samej podmiotowej strukturze, która u Lévinasa przybiera ostatecznie postać substytucji ${ }^{52}$, u Lacana

\footnotetext{
49 Tamże, s. 35.

50 Zob. tamże, s. 114-116.

51 Zob. tamże, s. 139.

52 Na temat substytucji zob. E. Lévinas Inaczej niż być lub ponad istota, przeł. P. Mrówczyński, Aletheia, Warszawa 2000, s. 190-219.
} 
zaś nicości, co w konsekwencji jest wnioskiem analogicznym ze względu na wypełnienie substytucji całkowicie Innym - po to, aby tożsamość mogła się ukonstytuować, musi zaniknąć na rzecz Innego. U obu myślicieli kwestią nierozstrzygniętą pozostaje możliwość pragnienia podmiotu będącego nicością. Wymusza to namysł nad naturą tej ostatniej. Dla Lévinasa nicość wydaje się mieć dwa znaczenia. Po pierwsze to il y a, czyli brak formy, ciemność, bezkształtność. Po drugie zaś nicość w pewnym sensie wiąże się z biernością podmiotu wobec anarchicznego dobra.

W teorii Lacana nicość wydaje się również występować pod dwiema postaciami. Po pierwsze, oznacza brak pełni, niekompletność, pęknięcie i w tym sensie podmiotowość jest niczym, tzn. nie ma jej - tworzy się ona i znika (rodzi się i umiera). Po drugie, nic to zaprzeczenie realności jako pełni. Co ciekawe, status pełni jest zupełnie poza niczym, stąd podmiot nie ma do pełni dostępu. Pełnia może być jedynie wyczuwalna, dzięki pragnieniu lub lękowi, jednak jej status stanowi dla podmiotu zagadkę, od której odbija się on jak od ściany - tak naprawdę nie wie on przecież, czy ona tam jest. Nigdy jej nie poznał. Gdyby nie koncepcje lęku i pragnienia przekraczające podmiotowe struktury, otwierające podmiotowość na zewnątrz, to dualizm koncepcji obu myślicieli wpisywałby się wprost w tradycję kartezjańską, na co zresztą, w odniesieniu do Lévinasa, wskazuje Wojciech Starzyński ${ }^{53}$.

W myśli Ricœura Inny najpełniej ujawnia się w porządku symbolicznym jako sumienie, kształtujące tożsamość soi od wewnątrz. Kategoria soi została wprowadzona jako określająca tożsamość w pewnej opozycji do klasycznego podmiotu wywodzącego się z kartezjańskiej tradycji. Istotą soi nie może być wyłącznie myślenie, lecz również działanie. To ostatnie zaś powinno być etyczne i moralne, tzn. subiektywność wyborów powinna być filtrowana przez intersubiektywne zasady. Geoffrey Dierckxsens podkreśla że, w przeciwieństwie do Kanta Ricœur zauważa egoistyczne skłonności człowieka, jednocześnie wskazując na konieczność stosowania uniwersalnych norm intersubiektywnych stojących na straży powszechnego porządku ${ }^{54}$. We wprowadzeniu tego rodzaju nadrzędnych instancji regulujących subiektywne działania widoczny jest jednak wpływ Kantowskiej teorii moralnej. Proponowana przez Ricœura „mała etyka” (petite éthique) zawiera zatem z jednej

53 W. Starzyński Neokartezjanizm fenomenologii francuskiej. Sartre, Merleau-Ponty, Levinas, Henry, Marion, Wydawnictwo IFiS PAN, Warszawa 2014, s. 179-219.

54 G. Dierckxsens The Ambiguity of Justice: Paul Ricœur on Universalism and Evil, "Études Ricœuriennes/Ricœur Studies" 2015 t. 6, nr 2, s. 32. 
strony subiektywne i osobiste dążenia etyczne. Z drugiej zaś obowiązek moralny wyrażający uniwersalną normę $e^{55}$. W kontekście lacanowskiej teorii oraz problematyki lęku oraz pragnienia, warto zapytać o status obu w myśli Ricœuera.

Niewątpliwie zarówno lęk, jak i pragnienie ugruntowane byłyby w strukturze soi w porządku subiektywnym. Niemniej wydaje się, że sumienie jako poświadczenie ${ }^{56}$ skutecznie ukierunkowuje oba obszary na określone wartości w procesie wypracowywania indywidualnej narracji przez soi. Jak u Lévinasa podmiotowość dobrowolnie i z samej swojej istoty otwierała się na Innego, tak u Ricœura, podobnie jak w lacanowskiej teorii, asymilacja struktur wyznaczanych przez Innego stanowi swego rodzaju konieczność. Lacan wskazywał na lęk sugerujący możliwość uznania owych struktur za obce podmiotowości - lęk jako zapowiedź ujawnienia prawdy na temat iluzji podmiotu. Ricœur zaś wskazuje na lęk etyczny ujawniający się za pośrednictwem języka symbolicznego ${ }^{57}$ :

Lęk przed nieczystym i obrzędy oczyszczenia leżą u podłoża wszystkich naszych uczuć i wszystkich zachowań związanych z przewiną. [...] Wraz ze skalaniem wkraczamy do królestwa Strachu. ${ }^{58}$

Autor Symboliki zła dowodzi, że lęk i strach wywołują w człowieku potrzebę etyki, sprawiedliwości i norm moralnych. Ujawnia także związek żądzy zemsty za wyrządzone zło z ideą sprawiedliwości. Wyrządzane zło zawiera już w sobie zalążek sprawiedliwej kary i odwrotnie ${ }^{59}$. Analizując symboliczny porządek kultury zachodniej, Ricœur wskazuje także na kulturotwórcze i mitotwórcze funkcje języka, za pośrednictwem którego lęk przed karą czy przed niebezpieczeństwem można wypowiedzieć, uzyskując przebaczenie, ukojenie bądź pomoc:

55 Zob. tamże, s. 33; Na temat wymowy "małej etyki” zob. M. Drwięga Paul Ricœur daje do myślenia, Homini, Bydgoszcz 1998, s. 180-183. Na temat podmiotowych możliwości zob. C. Sautereau Subjectivité et vulnérabilité chez Ricœur et Levinas, "Études Ricœuriennes/Ricœur Studies" 2013 t. 4 , $\mathrm{nr} 2$, s. 8-24.

56 Zob. m.in. G. Lubowicka Sumienie jako poświadczenie. Idea podmiotowości w filozofii Paula Ricœura, Wydawnictwo UWr, Wrocław 2000. P. Ricœur Symbolika zła, przeł. S. Cichowicz, M. Ochab, Aletheia, Warszawa 2015, s. 15-26.

58 Tamże, s. 33. 
Poprzez lęk przed ciosem, przed unicestwieniem przeziera proces przywracający porządek, jakikolwiek porządek. Przywrócone zostaje coś wprowadzonego, a potem usuniętego. Negacja potwierdza porządek.

Negatywny moment kary pozwala w ten sposób antycypować potwierdzone zwierzchnictwo pierwotnej nienaruszalności; odpowiednio, kara pomyślana jako zemsta jest negatywną otoczką o wiele pierwotniejszego zachwytu, zachwytu porządkiem, dowolnym porządkiem, nawet tymczasowym, nawet skazanym na zagładę. Nie ma prawdopodobnie takiego tabu, w którym nie tkwiłoby jakieś poszanowanie porządku, jakieś uznanie dla niego. I to niejasne, skłębione poczucie porządku ożywia strach świadomości uginającej się pod fatalnością cierpienia spowodowanego zemstą. ${ }^{60}$

Podobnie jak lęk, znaczenie pragnienia na poziomie etycznym zostaje przez Ricœura rozpoznane na gruncie językowym jako envie de (fr.) ochota zrobienia czegoś oraz jako wanting (ang.): chęć na zrobienie czy osiągnięcie czegoś61. Pragnienie w tej koncepcji można także odnosić do myśli Arystotelesa jako naturalne rozumne pragnienie bycia szczęśliwym ${ }^{62}$.Zostaje ono także powiązane z wolą, która może pomóc przezwyciężać lęk i kierować podmiotowość ku wolności. Autor Symbolikizła uznaje sublimację lęku w idei sprawiedliwości za jedyne rozsądne jego przezwyciężanie. Lęku nie sposób usunąć bezpośrednio, podobnie jak u Lacana lęk jest nieusuwalny oraz nie-do-usunięcia. Według Ricœura sublimacja lęku w procesie wychowania, tzn. wprowadzanie odpowiednich standardów etycznych i moralnych dają nadzieję na zmniejszanie lęku w codziennym ludzkim funkcjonowaniu ${ }^{63}$.

Zarówno więc w teorii Lacana, jak i u Lévinasa oraz Ricœura lęk pełni strukturującą funkcję kształtującą status podmiotowości względem tego, co zewnętrzne, czyli Innego. To ten ostatni odpowiada za ostateczny kształt podmiotu. Co prawda lęk w myśli Lévinasa nie został dostatecznie wyeksplikowany w całej koncepcji, jednakże, na podstawie analizy pragnienia, można zrekonstruować potencjalny status lęku u autora Inaczej niż być oraz domyślać się jego znaczenia. Wydaje się także, że dopuszczenie w ramach podmiotowej

60 Tamże, s. 54 .

61 Zob. P. Ricœur O sobie samym jako innym, przeł. B. Chełstowski, PWN, Warszawa 2005, s. 107.

62 Zob. tamże, s. 342.

63 Zob. tamże, s. 55-56. 
struktury lęku i pragnienia oraz wskazanie na nie jako na drogi kierujące ku Innemu fundującemu tożsamość podmiotu z jednej strony może zostać uznane za słabość filozofii podmiotu (podmiot jest kruchy, wydany Innemu, przez co nie może być samodzielną substancją). Z drugiej jednak wstępne analizy myśli powyższych autorów ukazują niemały potencjał w symbolicznym otwarciu podmiotowej struktury świadomej swoich słabości i mogącej kształtować własny, indywidualny los na podstawie wiedzy na temat własnej genezy, statusu oraz możliwości. W ten sposób i paradoksalnie podmiot wydaje się lepiej ugruntowany we własnej tożsamości - znając słabości, może próbować kierować je ku celom sobie wiadomym.

Na koniec zapytajmy może jeszcze tylko o status lęku w filozofii Immanuela Kanta, do którego Lacan dość często i chętnie nawiązuje. Czy uprawnione i możliwe byłoby zatem stwierdzenie, że to lęk determinuje imperatyw kategoryczny? Czy pragnienie wyniesienia Innego na poziom bezdyskusyjnie normatywny nakazuje utożsamienie podmiotowości z celem jako podmiotem wszelkich działań, nigdy zaś jako środkiem do celu?

Oczywiście odpowiedź na pierwsze pytanie jest uwarunkowana apriorycznymi przesłankami przyjętymi przez osobę odpowiadającą, stąd, bazując na założeniach przyjętych przez autora Krytyki praktycznego rozumu, lęk nie miałby nic wspólnego z imperatywem i sytuowałby się na gruncie „negatywnych" uczuć niebędących dla Kanta w ogóle przedmiotem rozważań. Lęk nie należy do uczuć moralnych. Przeciwnie, może stanowić przeszkodę w pracy nad tymi ostatnimi. Na gruncie tej myśli lęk można zestawić w jednym szeregu z kłamstwem, które pod żadnym pozorem nie powinno być tolerowane. Podmiot kierujący się imperatywem kategorycznym dokładnie wie, co powinien, w danej sytuacji, robić, czym się kierować, jakiego rodzaju decyzje podejmować.

Na pierwsze pytanie możliwa jest także odpowiedź tego rodzaju, jakiej udzielił Ricœur, również inspirując się Kantowską teorią: prawo moralne to sublimacja lęku, pośrednie przekształcenie tego ostatniego za pomocą odpowiednich zabiegów wychowawczo-edukacyjnych w pozytywną ideę regulującą także kwestię uczuć i emocji. Lacan podąża bardzo podobnym torem analizy, wskazując na brak odniesienia Kantowskiego imperatywu do rzeczywistości (jako opozycji do realnego). Imperatyw kategoryczny miałby odnosić się do Reczy (la Chose), którą można poznać wyłącznie za pośrednictwem prawa wyznaczającego miejsce pragnieniu ${ }^{64}$. Samo prawo jest wytwarzane

64 J. Lacan L'éthique de la psychanalyse. Le Séminaire. Livre VII, s. 97-102. 
poprzez sublimację, gdzie na poziomie prawa dochodzi do wygenerowania norm moralno-kulturowo-społecznych (prawa w rozumieniu Freuda). Pragnienie wypełniania i przestrzegania tych norm, czego przykładem może być imperatyw kategoryczny, prowadzi podmiot do odczuwania satysfakcji wypełniającej się nie tam, gdzie faktycznie powinna się ona wypełnić, czyli na poziomie realnego. Zarówno więc pragnienie, jak i satysfakcja dokonują się jak gdyby poza podmiotem ze względu na status pękniętej struktury, w jakiej ten ostatni funkcjonuje. Lęk więc pojawiałby się, jak zostało już zaznaczone wyżej, w momencie ewentualnej demaskacji sublimacji realizującej się w imperatywie kategorycznym.

Odpowiedź na drugie pytanie wiąże się z koniecznością dookreślenia pojęcia celu. Kant rozumiał cel w kategoriach bezinteresowności. Podmiot powinien być zawsze celem, nigdy środkiem do celu ze względu na swój nadrzędny, normatywny status. Lacan inaczej ujmuje celowość podmiotu. Ten ostatni to obiekt dla Innego i ze względu na niego. Podmiot stanowi cel działań Innego, nawet jeżeli uznaje własną autonomię, do której de facto nie jest zdolny. Celowość według Lacana zdecydowanie należy do rzeczywistości, podobnie jak pragnienie, któremu, jak zostało już kilkukrotnie zaznaczone wyżej, miejsce wyznacza prawo. Stąd odpowiedź na pytanie drugie musi być raczej twierdząca, ze względu na wspomnianą już także strategię adaptacyjną podmiotu do rzeczywistości, jaką jest sublimacja lęku - w tym wypadku w ideę autonomicznego podmiotu ustanawiającego prawo. Tego rodzaju konstrukt nie podlega rzeczywistości, lecz ją reguluje, stąd nie może być on traktowany jako obiekt. Przeciwnie, autonomiczny podmiot zostaje ustanowiony na miejscu Innego, tam, gdzie nie ma nic. Stąd pragnienie, jak podkreśla Lacan, chybia celu i dąży nie do tego, do czego powinno dążyć, "obchodząc" niejako faktyczny obiekt pragnienia.

\section{Podsumowanie}

Podsumowując niniejsze rozważania, należy stwierdzić, że, po pierwsze, podmiotowość gruntuje osobistą, prywatną i niepowtarzalną strukturę za pośrednictwem lęku przed utratą iluzji bycia tożsamością. Nie jest ona stabilna. Przeciwnie jej kruchość wymaga od podmiotowości powtarzania rytuałów własnych narracji i opowieści ugruntowujących ją w niezwykle słabych i wątłych strukturach. Jednak to dzięki lękowi podmiotowość utożsamia się z własnym człowieczeństwem, tworząc kulturę, jej symbole, mity, porządek norm moralnych i społecznych. 
Po drugie, Lacan w bardzo dosadny sposób wydobywa na jaw problematyczność normatywnego statusu prawdy w obrębie podmiotowych struktur. Skutkuje to relatywizowaniem prawdy w obrębie podmiotowych możliwości odbioru. Genezę ograniczonej percepcji i poznawania wprowadza struktura podmiotowości jako cielesności.

Po trzecie, w analizach lęku zostaje uwypuklone zjawisko dialektyki podmiotowości i Innego, zapośredniczania się jej w tym ostatnim poprzez pragnienie bycia uznanym, akceptowanym. To dzięki Innemu podmiotowość w ogóle ma szanse wychodzić na jaw we własnej kruchości, mogącej być jednocześnie jej siłą, jak mawiał Pascal ${ }^{65}$.Ta ostatnia miałaby polegać na ciągłości obrony siebie samego i otoczenia przed niebezpieczeństwem osunięcia się w nicość, brak formy, ciemność. Na ten fakt wskazuje zarówno Lacan, jak i Lévinas - bez struktur (które Ricœur i inni utożsamiają z wartościami) podmiotowość nie miałaby szansy na zaistnienie, a tym, co decyduje o jej unikalności, są m.in. lęk i pragnienie Innego.

65 B. Pascal Myśli, przeł. T. Żeleński (Boy), Pax, Warszawa 1983, S. 107 [par. 264]. 


\section{Abstract}

\section{Marta Szabat}

JAGIELLONIAN UNIVERSITY MEDICAL COLLEGE (CRACOW)

The Philosophical Potential of Subjectivity in the Light of Jacques Lacan's Concept of Fear

Taking Jacques Lacan's concept of fear as a starting point, Szarbat examines the philosophical potential of subjectivity. The first half of the article focuses on the concept of fear in the light of Lacan's theory of subjectivity. Here, fear does not lack an object but always refers to one, signalling cuts in the sphere of the subject's structure. It appears where that structure is marked by shattering, fragmentation or lack of unity, and it is closely related to the desire of the Other. Szabat's analyses is based on Lacan's fullest account of his theory of fear in his seminar L'angoisse. The second part complements Lacan's considerations on subjectivity and fear with reflections on fear and desire by philosophers such as Emmanuel Lévinas and Paul Ricoeur. Szabat also enriches the debate on the potential of subjectivity that results from the ability to experience fear and desire by referring to the moral philosophy of Immanuel Kant, a frequent reference for Lacan.

\section{Keywords}

desire, fear, subject, other, affect 